Version accepted for publication

The TQM Journal

ISSN: 1754-2731

\title{
Locally focused and digitally oriented: examining eco-museums' digitization in a service quality management perspective
}

DOI: 10.1108/TQM-02-2021-0046

Rocco Palumbo, University of Rome Tor Vergata;

Maria Ciasullo, University of Salerno;

Massimiliano M. Pellegrini University of Rome Tor Vergata;

Andrea Caputo, University of Trento \& University of Lincoln;

Mario Turco, University of Salento;

\begin{abstract}
Purpose: Eco-museums safeguard the cultural authenticity and the historical identity of the place in which they operate. Conventional organizational models and management practices are generally employed to achieve this institutional aim. Conversely, innovative solutions - such as digitization - are overlooked. Adopting a service quality management perspective, the article intends to examine the role of managerialization and professionalization in triggering eco-museums' digitization.
\end{abstract}

Methodology: An empirical analysis involving 126 eco-museums operating in Italy as of 2018 was designed to investigate the implications of managerialization and professionalization on the eco-museums' propensity to embark on a digitization process. Two different forms of digitization were examined: 1) the presence of eco-museums in the digital environment; and 2) the exploitation of digital tools for service delivery. The mediating role of two "soft" Total Quality Management (TQM) practices, i.e. people centredness and strategic focus on visitors' experience, was contemplated in the empirical analysis.

Findings: The research findings suggest that managerialization and professionalization have ambiguous effects on eco-museums' digitization. Nevertheless, they indirectly contribute to a greater digital presence of eco-museums and to a larger use of digital tools for service delivery through an increased use of soft TQM practices.

Practical Implications: Managerialization and professionalization are likely to foster the digital transition of eco-museums, which advances their ability to protect and promote the local cultural heritage. Soft TQM practices intended to achieve people-centredness and to enhance the visitors' experience should be exploited to stimulate the eco-museums' digitization.

Originality: The article examines the triggers of eco-museums' digitization, providing some food for thought to scholars and practitioners.

Keywords: Eco-museums; Digitization; Managerialization; Professionalization; Soft TQM. 


\section{Introduction and study rationale}

Eco-museums are a unicum in the realm of cultural institutions (Lindeqvist and Oscarsson, 2004). Their institutional aim is to contribute to a tripartite purpose consisting of: 1) cultural heritage promotion; 2) territorial identity protection; and 3) sustainable local development (Doğan and Timothy, 2020). Eco-museums are established on an idea of community empowerment (Kaur, 2019), which enacts a viable preservation of the local cultural heritage (Liu, 2014). More specifically, they can be conceived of as "... a mirror in which the local population views itself to discover its own image, in which it seeks an explanation of the territory to which it is attached and of the populations that have preceded it, seen either as circumscribed in time or in terms of the continuity of generations" (Rivière, 2009: p. 182). From this standpoint, eco-museums are complex and living institutions, which strive for involving relevant stakeholders and visitors in an engaging cultural experience intended to communicate the territorial identity and to preserve traditions, values, and beliefs inherited from the past (Griffin-Kremer, 2020).

Scientific literature is paying an increasing attention to eco-museums, considering them as the result of the need for rediscovering local cultures and safeguarding them from the homogenization brought by globalization (Donghai, 2008). Scholars involved in this research stream have investigated different management topics, ranging from the challenges and issues related to the establishment of an eco-museum (Massing, 2019) to the assessment of the value produced by the cultural activities provided by these institutions (Corsane et al., 2007). However, to the best of the authors' knowledge, there is limited agreement about the peculiar organizational features of eco-museums, as well as about the institutional and management factors that underpin their effectiveness (González et al., 2017). Inter alia, literature quarrels over the triggers that foster the eco-museums' digitization (Sánchez, 2020). This is a major gap in the scientific knowledge, since digitization is crucial to enable ecomuseums to recontextualize their activities aimed at cultural heritage promotion in a service quality management perspective (Aiba and Sasatani, 2004). 
The exploitation of Information and Communication Technologies (ICTs) to improve the ecomuseums' effectiveness and to advance their ability to attain a viable preservation of the local cultural heritage has been emphasized in previous studies (e.g., Llanos, 2015; Fernández-Hernández et al., 2020). Eco-museums' digital transformation has been argued to generate multiple gains (Ciasullo et al., 2015). Firstly, it allows to recontextualize the eco-museums' presence in the cyber-physical environment, improving their capability to communicate local cultures and traditions and to preserve their authenticity (Pan et al., 2012). Secondly, it enacts a more sustainable fruition of the cultural offering, contributing to enhance the eco-museums' institutional relationships with relevant stakeholders (Howard, 2002). Thirdly, digitization is thought to augment the cultural experience that is delivered to visitors, enacting a virtualization of the eco-museums' service offering (Lin et al., 2019). Lastly, yet importantly, digitization may support the heritage literacy of residents and visitors, which is essential to engage them in value co-creation (Ciasullo et al., 2018; Babić et al., 2019) and to put people at the centre of eco-museums' management (Bae and Lee, 2012; Kim and Lee, 2013).

The cultural institutions' managerial transformation has been associated with their proclivity to expand their institutional boundaries in the cyber-physical domain and to leverage digital tools and ICTs to improve their attractiveness (Colbence and Sabatier, 2014; Cappa et al., 2020). In addition, cultural institutions' professionalization has been maintained to increase their ability to thrive in the digital domain, reshaping conventional organizational structures and management practices in light of the unfolding challenges faced by eco-museums in the cyber-physical environment (Given and McTavish, 2010). Both managerialization and professionalization have been claimed to indirectly contribute to the reconfiguration of the spatio-temporal context of museums' activities through soft Total Quality Management (TQM) practices, i.e. by stimulating a greater people-centredness and promoting the adoption of a focus on the visitors' experience in crafting the cultural service offering (Williams, 1998; Rossato and Castellani, 2020). In spite of these considerations, limited evidence is available on the implications of managerialization and professionalization on the eco-museums' ability to accomplish a digital transition. The article attempts to fill in this gap, illuminating the role 
of managerialization and professionalization in stimulating the eco-museums' readiness to recontextualize their presence in the digital environment and to take advantage of digital tools to improve their service offering. Three Research Questions (R.Q.) inspired this article:

R.Q. 1: Does managerialization trigger a greater willingness of eco-museums to undertake a digital transformation?

R.Q. 2: Does professionalization engender a recontextualization of eco-museums' presence and activities in the digital environment?

R.Q. 3: Does soft TQM affect the implications of managerialization and professionalization on eco-museums' digitization?

An empirical study was designed to answer these research questions. The article is organized as follows. Section 2 depicts the conceptual background against which the research was conceived and advances the research hypotheses. Section 3 describes the methodology used to collect data and illustrates the statistical approach which was implemented to obtain evidence on the role of managerialization and professionalization in triggering the eco-museums' digitization. Section 4 reports the study findings, which are critically discussed in Section 5. Lastly, Section 6 finalizes the article, stressing the study's conceptual and practical implications.

\section{Conceptual background}

Cultural institutions are undergoing a steady managerialization which is reshaping their institutional identity and their organizational attributes (Zan, 2006; McCall and Gray, 2014; Ciasullo et al., 2016). Managerialization primarily determines a transformation of value creation processes and activities implemented by cultural institutions, paving the way for the adoption of business-like organizational practices (Lindqvist, 2012). The adoption of a managerial perspective to run cultural institutions is consistent with a service ecosystem view (Ciasullo et al., 2018), according to which cultural institutions strive for handling the intertwined economic, social, and environmental 
challenges which affect their purpose of protecting and promoting the cultural heritage (Zutshi et al., 2021).

Managerialization goes hand in hand with the professionalization of cultural institutions (Falk and Sheppard, 2006). Whilst managerialization involves technical advancements aimed at redefining the institutional and organizational activities implemented by cultural institutions, professionalization acts at a deeper level, entailing the specialization of responsibilities and roles assigned to decision makers (Harrison, 1994). Professionalization is rooted in an ideology of expertise, independence, and integrity (Grey, 1997). Besides, it echoes the adoption of an actor-centred perspective, which reframes the cultural institutions' activities in light of the specific needs and expectations perceived by external stakeholders (Björkdahl and Kappler, 2019).

Both managerialization and professionalization act as stimuli for the digital transformation of cultural institutions (Mannoni, 1996; Wenchang, 2008). This is especially true for eco-museums, which can exploit ICTs and digital tools to increase their ability to accomplish their institutional purpose (Di Pietro et al., 2014; Palumbo et al., 2021). Eco-museums' digitization can be conceived of as a two-fold phenomenon. On the one hand, it implies the repositioning of cultural institutions in the cyber-physical environment, expanding the range of interactions they are able to establish with relevant stakeholders (Liu and Tan, 2019). On the other hand, it involves the enrichment of the cultural offering with digital services, enabling a vivid and dynamic exchange with visitors (Scrofani and Ruggiero, 2013). Digitization opens additional spaces for value co-creation, fostering a ubiquitous connection between eco-museums and relevant stakeholders (Pesce et al., 2019). Moreover, it provides eco-museums with innovative solutions to augment the visitors' experience, advancing the individual ability to appreciate the authenticity and the richness of the cultural heritage (Trunfio et al., 2020). This is possible by engaging people in immersive activities enacted by virtualization, artificial intelligence, and gamification (Errichiello et al., 2019; Virto and López, 2019). 
Managerialization inspires the design and the implementation of tailored strategies and practices which take advantage of digitalization to reconfigure the activities of cultural institutions (Myrczik, 2020). More specifically, it determines a greater willingness of cultural institutions to exploit ICTs and digital tools to enhance the cultural institutions' attractiveness (Mingsiritham and Chanyawudhiwan, 2019). Professionalization leads to a greater acknowledgement of available opportunities to capitalize on digital technologies and web-based services in an attempt to improve the visitors' experience (Wiastuti et al., 2020). Alongside increasing the eco-museums' attractiveness, this strengthens their capability to promote and protect their cultural heritage (Mason, 2020). Drawing on these arguments, it is hypothesized that:

Hp. 1: Managerialization triggers the eco-museums' digitization;

Hp. 2: Professionalization positively affects the digital transformation of eco-museums.

The effects of managerialization and professionalization on the eco-museums' readiness to implement a digital transformation is mediated by two factors, which are related to their service delivery approach (Manna and Palumbo, 2018). As previously anticipated, managerialization and professionalization boost the redesign of eco-museums' activities and practices in a service quality perspective, giving a greater emphasis to formal and informal TQM practices (Williams, 1998; Barile et al., 2017). The managerial turn brings with itself a people-centred perspective to mould and deliver the cultural service offering (Romanelli, 2020), which is a key component of business excellence, as well as a driver of service quality (Milton-Smith, 1995). Similarly, professionalization sustains the openness of cultural institutions towards customers and relevant stakeholders as a strategic proposition to upgrade their organizational attractiveness (Maye et al., 2017). This prompts a focus of eco-museums on the evolving needs and expectations of visitors in an attempt to devise a customized visiting experience (Sandifer, 2003). An increased attention of eco-museum to peoplecentredness is thought to determine a greater organizational propensity to digitize current strategies, structures, and operations to accomplish a co-creating interaction with visitors and stakeholders (Ciasullo et al., 2018; Doukianou et al., 2020). Actually, digitization allows eco-museums to reframe 
their relationship with stakeholders, making it possible to adopt a fully-fledged people-centred perspective in articulating their cultural service offering (Parry, 2019). Hence, it is assumed that:

Hp. 3: People-centredness positively mediates the relationship between managerialization and the eco-museums' digital transformation;

Hp. 4: People-centredness positively mediates the relationship between professionalization and the eco-museums' propensity to undertake a digital transformation.

People centredness encompasses an enrichment of the visiting experience delivered to visitors (Jelincic and Senkic, 2017). The more the eco-museums adopt a people-centred perspective, the more they are encouraged to expand and improve their cultural service offering. This is possible by including additional services, such as live events, shows, and historical commemorations, which are directed at increasing the value perceived by visitors (Vermeeren et al., 2018). The intention to improve the visiting experience leads to a larger exploitation of digital tools and ICTs to engage visitors beyond the physical space and to establish with them an immersive exchange (Petrelli et al., 2018). Digitalization enables cultural institutions to meet the visitors' expectation to get a greater control over the visiting experience (Yu and Wang, 2020). Moreover, it increases the eco-museums' ability to improve the customers' enjoyment of their cultural offering through a balanced mix of edutainment initiatives (Nofal et al., 2020). From this point of view, it is forecasted that:

Hp. 5: The focus on visitors' experience positively mediates the relationship between managerialization and the digital transformation of eco-museums;

Hр. 6: The focus on visitors' experience positively mediates the relationship between professionalization and the propensity of eco-museums to undertake a digital transformation.

People-centredness and the focus on visitors' experience have been proposed as soft TQM practices to boost the digitization of cultural institutions, augmenting their ability to enhance the cultural service offering sticking to a service quality management perspective (Brenton and Bouckaert, 2020). People-centredness envisages a rethinking of cultural institutions, stimulating the 
transition towards a value co-creation approach which is tailored to cultural heritage protection and promotion (Carnegie and Mccabe, 2008). The focus on visitors' experience which derives from such a rethinking implies a greater attention paid to the manifold attributes of the cultural experience. Ecomuseums are solicited to establish a more direct and meaningful exchange with visitors, who are engaged into a transformational process which kicks off by entering in contact with the cultural heritage (Palumbo et al., 2021). Drawing on these considerations, it is assumed that a serial mediation path links managerialization and professionalization to digitalization through the indirect role of people-centredness and focus on visitors' experience (Ciasullo et al., 2015). Therefore, two additional hypotheses are proposed:

Hp. 7: People-centredness and the focus on visitors' experience serially mediate the relationship between managerialization and the digital transformation of ecomuseums;

Hp. 8: People-centredness and the focus on visitors' experience serially mediate the relationship between professionalization and the propensity of eco-museums to undertake a digital transformation.

\section{Methods}

\subsection{Research Design}

A serial mediation analysis was designed to collect evidence on the direct and indirect implications of eco-museums' managerialization and professionalization on their propensity to undertake a digital transformation. Sticking to the conceptual framework depicted above, four statistical models were elaborated. Two models were intended to obtain insights into the role of managerialization in triggering a digital turn of eco-museums, whilst the other two focused on the implications of professionalization on eco-museums' digitalization. Two forms of digitization were investigated. More specifically, attention was paid both to the digital presence of eco-museums in the cyber-physical domain and on the introduction of web-based digital services to improve the visitors' 
experience. The eco-museums' propensity to implement a people-centred approach in managing their cultural activities and their strategic orientation towards the enrichment of the visitors' experience were included as the mediating variables in the four statistical models, accounting for the role of soft TQM in fostering the eco-museums' digitization. Figure 1 graphically depicts the statistical models which were investigated in this empirical research.

[Please, put Figure 1 about here]

The approach proposed by Hayes (2018), which relies on 5,000 bootstrap samples and on Ordinary Least Square (OLS) regression-based path analysis, was used. All elaborations were run through the Statistical Package for Social Science (SPSS, v. 24). Model no. 6 of the MACRO process embedded in SPSS was implemented: it allowed us to obtain consistent results about the direct and indirect implications of managerialization and professionalization on eco-museums' digitization (Hayes et al., 2017).

\subsection{Variables}

Secondary data were collected from the latest national survey on museums and cultural institutions operating in Italy. Data were compiled by the Italian Institute of Statistics (ISTAT) in 2018 and they were made available in early 2020 according to a Creative Common Licence 3.0. As recommended by ISTAT (2018), available data were exclusively used for research purposes. Since ISTAT was not directly involved in this study, the research findings should be ascribed to the authors exclusively. In line with the research purposes, only eco-museums were admitted in the analysis. Hence, the study sample consisted of 126 organizations. Data were stored in an electronic worksheet to systematize the variables which were run in statistical elaborations.

A heuristic approach was used to operationalize the main dimensions investigated in this study. Managerialization was assessed as the eco-museums predisposition to adopt business-like practices to accomplish their organizational activities (Palumbo et al., 2021). Different items were 
contemplated to compute the managerialization score of eco-museums, such as the introduction of a management system to monitor organizational activities and the arrangement of a service charter to enhance the eco-museum's relationship with visitors and stakeholders. The managerialization score was an interval scale variable, ranging from 1 (lowest level of managerialization) to 5 (highest level of managerialization). Professionalization was assessed in light of the specializations available to address the management challenges faced by eco-museums. As recommended by the scientific literature (Striebing, 2017; Hwang and Powell, 2009), both the composition of the management team and the professional expertise of each management member were assessed to gauge museums' professionalization. The larger the availability of specializations, the greater the professionalization of eco-museums. Professionalization was operationalized as an interval scale variable, ranging from 1 (lowest degree of professionalization) to 5 (greatest degree of professionalization).

The digital presence of eco-museums assessed the propensity of the units of analysis to exploit digital tools and ICTs to build sound relationships with external stakeholders (Ahmed et al., 2020). The more varied the channels used by eco-museums to interact with relevant stakeholders in the cyber-physical environment, the greater their digital presence. Moreover, the introduction of webbased services to enrich the service offering delivered to visitors was investigated (Piancatelli et al., 2020). It was assumed that the more varied the eco-museums' digital service offering, the more pervasive their digitalization. The scores related to the digital presence and to the delivery of webbased services were measured as interval scale variables, ranging from of 1 (lowest level of digitization) to 5 (highest level of digitization).

People-centredness was assessed by looking at the design of customer-oriented ancillary services which complemented the traditional cultural activities performed by eco-museums in a perspective of enhanced service quality (Traboulsi et al., 2018). The inclusion of additional services - such as live events, shows, and commemorations - in the eco-museum's service offering was identified as a signal of people-centredness (Manna and Palumbo, 2018). The focus on the visitors' experience was investigated in light of the eco-museums' willingness to enrich the customers' visiting 
experience by expanding the cultural offering with value-added services, including customized guided tours, proactive information delivery, and customer-centred visit assistance (Conti et al., 2020). These two mediating factors were assessed as interval scale variable, ranging from 1 (lowest use of soft TQM practices) to 5 (highest use of soft TQM practices).

\subsection{Sample}

Table 1 reports the institutional characteristics of the study sample. North-western $(37.3 \%)$ and North-eastern Italy (21.4\%) accounted for more than half of the eco-museums. Central Italy followed, representing slightly less than a fourth of the sample (23.8\%). Main Italian Islands (11.9\%) and Southern Italy (5.6\%) hosted about 1 in 6 eco-museums. The majority of cultural institutions were primarily focused on ethnography and anthropology (31.7\%). Local historical heritage (16.7\%), history (15\%), archaeology (9.5\%), and modern and contemporary arts $(8.7 \%)$ followed.

[Please, put Table 1 about here]

A large part of the sample was founded during the $21^{\text {st }}$ Century (49.1\%). More than 2 in 3 eco-museums were inaugurated in the second half of the $20^{\text {th }}$ Century (46.9\%). Only 5 eco-museums were established in the first half of the $20^{\text {th }}$ Century or earlier (4\%). A third of cultural institutions were privately owned (35.6\%), whilst public sector entities owned 81 eco-museums (64.4\%). Municipalities were the single major owner of eco-museums involved in the analysis (59.5\%). On average, the eco-museums had an average number of 6 employees $(\sigma=6.5)$, ranging from a minimum of 1 employee to a maximum of 50 employees. The average exposition area was 740 square meters $(\sigma=982.10$ square meters $)$.

\section{Findings}

Some descriptive statistics allow us to get an overview of the eco-museums' attributes in terms of managerialization, professionalization, and digitization. On average, the eco-museums showed an 
adequate managerialization score $(\mu=2.68 ; \sigma=1.28)$. About 1 in 5 cultural institutions reported a limited managerialization (19.8\%): they did not implement business-like strategies and tools to drive their organizational activities. The professionalization score was lower than the managerialization one $(\mu=2.19 ; \sigma=1.40)$. Half of the eco-museums disclosed a limited or very limited specialization of roles and competencies. The digitization score was relatively low, too. On the one hand, the ecomuseums reported a limited presence in the cyber-physical domain $(\mu=2.07 ; \sigma=0.96)$. On the other hand, they were not used to recontextualize their service offering in the digital context, providing only a narrow array of web-based services to visitors $(\mu=1.81 ; \sigma=1.03)$. In spite of these considerations, about 1 in 8 eco-museums was found to have a good presence in the digital environment (12.5\%), whilst 1 in 6 institutions was used to deliver both physical and digital services to visitors $(15.9 \%)$. The eco-museums were found to perform well in terms of people-centredness and visitors' experience. The average people-centredness score was satisfying $(\mu=2.99 ; \sigma=1.14)$, with 4 in 10 eco-museums stating a relevant predisposition to arrange people-centred practices to improve their attractiveness $(41.3 \%)$. The units of analysis disclosed a significant focus on the enrichment of the visitors' experience $(\mu=3.20 ; \sigma=1.05)$. In particular, about half of them reported that the improvement of visitors' experience was a key factor underpinning decisions related to cultural services' delivery $(49.2 \%)$.

Table 2 provides an overview of the outcome of the four serial mediation models. Alongside the main variables depicting the key phenomena investigated in this study, some covariates were contemplated in order to check the consistency of the study findings. More specifically, three covariates were run in the statistical model: 1) the eco-museums' organizational dimension (measured according to the number of employees); 2) their institutional ownership (public or private ownership); and 3) their geographical location (main geographical areas of Italy).

[Please, put Table 2 about here]

Model 1 investigated the direct and indirect effects of managerialization on the eco-museums' digital presence. Managerialization was found to positively and significantly affect the propensity of 
eco-museums to recontextualize their presence in the digital environment (Coeff. $=0.15$; significant at the 0.05 level). The institutions which disclosed a greater managerialization were more likely to use digital tools and ICTs to manage their interactions with relevant stakeholders. Neither the dimension nor the ownership of eco-museums seemed to affect their presence in the digital environment. However, geographical location was positively and significantly related to this form of digitalization $($ Coeff. $=0.32$; significant at the 0.05 level): eco-museums established in Norther Italy were more likely to have a digital presence. Whilst people centredness did not influence the digital presence of eco-museums, the strategic focus on the visitors' experience triggered an increased predisposition of cultural institutions to thrive in the cyber-physical context (Coeff. $=0.24$; significant at the 0.001 level). People-centredness did not act as a mediating variable in the relationship between managerialization and digitalization. Otherwise, the strategic focus on the visitors' experience acted as a positive and statistically significant positive mediator (Coeff. $=0.07$; significant at the 0.01 level). The serial mediation was not significant. However, the total indirect effect of managerialization on eco-museums' digital presence was positive and statistically significant (Coeff. $=0.14$; significant at the 0.01 level).

Model 2 concerned the implications of managerialization on the provision of digital services to customers. Managerialization was not found to entail a greater willingness of eco-museums to take advantage on ICTs to reframe their activities related to cultural heritage protection and promotion. Also, the covariates did not seem to affect this type of eco-museums' digitization. Whilst peoplecentredness did not anticipate a larger use of digital tools to deliver cultural services to customers, the strategic focus on the visitors' experience was positively and significantly related to the ecomuseums' recontextualization of their service provision in the cyber-physical domain (Coeff. $=0.40$; significant at the 0.001 level). Even though managerialization did not have a direct effect on the ecomuseums' predisposition to exploit digital tools and ICTs to reshape their cultural offering, it was found to have a significant indirect effect as mediated by a strategic focus on visitors' experience $($ Coeff. $=0.12$; significant at the 0.01 level). People centredness did not act as a mediating variable 
in the relationship between managerialization and digitization of eco-museums' service delivery. Once again, the serial mediation was not statistically significant. Nevertheless, the total indirect implications of managerialization on digitization were positive and statistically significant (Coeff. $=$ 0.22 ; significant at the 0.01 level).

Model 3 dealt with the implications of professionalization on the eco-museums' digital presence. Professionalization performed as a positive and statistically significant determinant of ecomuseums' willingness to use digital tools and ICTs in order to interact with relevant stakeholders (Coeff. $=0.19$; significant at the 0.01 level). The more the cultural institutions recurred to professionalization, the more they exploited digital solutions to enhance their ability to accomplish their institutional aims. Covariates were not found to influence the digital presence of eco-museums, with the sole exception of geographical location $($ Coeff. $=0.37$; significant at the 0.001 level). On the one hand, people-centredness did not affect the digital presence of the eco-museums. On the other hand, a strategic focus on visitors' experience enacted a greater digital presence of eco-museums $($ Coeff. $=0.22$; significant at the 0.05 level $)$. Whilst people-centredness did not act as a significant mediator in the relationship between professionalization and digital presence of eco-museums, the strategic focus on visitors' experience positively and significantly mediated the effect of professionalization on digitization (Coeff. $=0.06$; significant at the 0.01 level). Serial mediation was not significant. However, the total indirect effect was positive and statistically significant (Coeff. = 0.12 ; significant at the 0.01 level).

Model 4 addressed the relationship between professionalization and the eco-museums' exploitation of digital tools to deliver their cultural offering. Professionalization did not have a significant direct effect on this form of digitization. The same was true for covariates, which did not display statistically significant coefficients. Both people-centredness (Coeff. $=0.24$; significant at the 0.001 level) and a strategic focus on visitors' experience (Coeff. $=0.46$; significant at the 0.001 level) were positively and significantly related to the use of digital tools and ICTs to enrich the ecomuseums' service delivery. Whilst people-centredness did not mediate the relationship between 
professionalization and digitization of cultural services, the strategic focus on visitors' experience had a positive and statistically significant mediating role (Coeff. $=0.13$; significant at the 0.01 level). The serial indirect effect of people-centredness and strategic focus on visitors' experience was not significant. The total indirect effect was positive and statistically significant (Coeff. $=0.23$; significant at the 0.01 level).

\section{Discussion}

Table 3 synthesizes the main findings of this empirical study, contextualizing them to the research hypotheses. Managerialization and professionalization had ambiguous effects on ecomuseums' digitization. On the one hand, managerialization triggered a greater propensity of ecomuseums to take care of their digital presence in order to establish more direct and straightforward interactions with relevant stakeholders (Palumbo et al., 2021). This is consistent with the purpose of bringing virtuality on the scene to identify new models and approaches to accomplish the protection and promotion of cultural heritage (Müller, 2002). Managerialization determines a greater maturity in undertaking a digitization process, which reframes the organizational identity of cultural institutions in the digital environment (Guarino et al., 2020). However, managerialization did not have a role in improving the eco-museums' predisposition to recontextualize their service offering in the digital environment (Brenton and Bouckaert, 2020). Professionalization had similar implications on eco-museums' digitization. Whilst it drove a greater digital presence of cultural institutions, it did not imply a larger use of ICTs and digital tools to deliver cultural services to visitors (Ciasullo et al., 2018). This situation can be explained in light of the partial contribution of professionalization in filling in the knowledge and competence gap which prevent the digital transformation of ecomuseums (Given and McTavish, 2010), paving the way for a recontextualization of their interorganizational relationships in the cyber-physical context (Dibitonto et al., 2020). In sum, Hp. 1 and Hp. 2 were partially supported. 
[Please, put Table 3 about here]

Soft TQM practices had a limited role on the process of eco-museums' digitization. Peoplecentredness did not mediate the implications of managerialization and professionalization on digitization (Ciasullo et al., 2015). This result contrasts with the arguments of scholars who maintain that the digital transformation of cultural institutions is primarily triggered by the intention to devise a people-centred cultural service offering, which is able to effectively meet the evolving demands of the community (Minoska-Pavlovska, 2019). Conversely, the eco-museums' strategic focus on the enhancement of the visitors' cultural experience positively and significantly mediated the effects of managerialization and professionalization on digitization (Elgammal et al., 2020). The eco-museums which performed better in terms of managerialization and professionalization were more likely to pay a greater attention to the enrichment of the visitors' experience (Agostino and Arnaboldi, 2021), which - in turn - stimulated a greater effort to exploit ICTs and digital technologies to establish a better relationship with customers (De Bernardi et al., 2019). Hence, whilst $H p .3$ and $H p .4$ were not supported, Hp. 5 and Hp. 6 were upheld.

The indirect effects of managerialization and professionalization on eco-museums' digitization serially mediated by people-centredness and focus on visitors' experience were positive, but not statistically significant. Notwithstanding, the total indirect effect of managerialization and professionalization on digitization were positive and statistically significant. From this point of view, Hp. 7 and Hp. 8 were not supported. As argued in literature, the evolving processes of cultural institutions' managerialization and professionalization is determining a greater attention paid to the design of people-centred cultural services. This is expected to improve the institutional attractiveness of cultural institutions towards current and prospective customers (Manna and Palumbo, 2018). Moreover, it engenders increased strategic and management efforts to enrich the visitors' experience, in order to engage them in the promotion and dissemination of cultural heritage (Brida et al., 2016). The aims of improving the people-centredness of cultural activities and of advancing the visitors' experience foster a greater propensity of eco-museums to undertake a digital transformation (Giannini 
and Bowen, 2019). In line with these considerations, the digital presence and the exploitation of ICTs to deliver cultural services have been largely considered to be the result of a reconfiguration of cultural institutions' strategies and practices in a perspective of customer-orientation and service quality management (Tesoriero et al., 2014; Devine and Tarr, 2019).

Several limitations affected this study: acknowledging them allows us to better contextualize the research findings and to envision avenues for further developments. Firstly, only eco-museums established in Italy were contemplated in the analysis. This constrains the generalization of the study results. However, since the whole population of Italian eco-museums was contemplated in the empirical analysis, it is possible to maintain the research findings' dependability. Secondly, the use of secondary data did not permit us to tailor the data collection to the specific purposes of this study. Notwithstanding, the data provided by ISTAT were consistent with the research aims and represented a consistent source to provide an answer to the questions that inspired this study. Thirdly, the crosssectional approach adopted in this research provided us with a snapshot of the state of the art of ecomuseums' digitization; however, it prevented from collecting evidence about the lengthwise implications of managerialization and professionalization on digitization.

Further research is required to fully illuminate the factors which stimulate the eco-museums' propensity to undertake a digital transformation which is intended to improve their ability to protect and promote their cultural heritage. An expansion of the geographical boundaries within which this research was conducted may pave the way for the collection of more dependable and generalizable evidence. Moreover, adopting a longitudinal perspective to investigate the direct and indirect implications of managerialization and professionalization on eco-museums' digitization may provide us with more consistent insights, capturing the manifold implications of the managerial turn which is characterizing cultural institutions across the word. In-depth qualitative studies are required to push forward our understanding of the challenges that are faced by eco-museums to achieve a greater presence in the digital environment and to take advantage of ICTs to enrich their cultural service offering. Finally, yet importantly, a focus on particular types of eco-museums, which can be 
discriminated in light of their organizational dimensions (small-sized eco-museums $V s$ medium and large-sized eco-museums) and to their subject areas (e.g. eco-museums focused on archaeology $V S$ eco-museums focused on history), may generate more nuanced empirical evidence on the implications of managerialization and professionalization on digitization.

\section{Conclusions}

The evidence collected in this study provides some food for thought to answer the research questions. Managerialization and professionalization had positive implications on eco-museums' digitization. They entailed a greater propensity of eco-museums to recontextualize their presence in the digital environment, fostering their ability to protect, promote, and disseminate the cultural heritage in a cyber-physical environment. However, neither managerialization nor professionalization engendered a larger use of ICTs and digital tools to enrich the service offering delivered to current and prospective customers.

It is worth noting that managerialization and professionalization implied the adoption of a people-centred approach in designing and delivering the eco-museums' services. Moreover, they stimulated a strategic focus on the improvement of the visitors' experience to increase the ecomuseums' attractiveness. Nonetheless, people-centredness did not affect the relationship between managerialization, professionalization, and digitization. Conversely, the strategic focus on visitors' experience acted as a positive and significant mediator which propelled the implications of managerialization and professionalization on eco-museums' digitization. From this point of view, it can be argued that, if properly handled, soft TQM may contribute in enhancing the effects of managerialization and professionalization on eco-museums' digitization.

The implications of this research are twofold. From a conceptual point of view, it emphasizes that, even though they represent different steps in the modernization of business models and organizational practices implemented by cultural institutions, managerialization and 
professionalization should be conceived as two faces of the same coin. Entailing the arrangement of business-like approaches to steer the functioning of eco-museums, managerialization may contribute in increasing their organizational adaptability, encouraging a digital transformation as a way of achieving a greater fitness with the external environment. Moreover, bringing in specialized competences and advanced knowledge related to the manifold areas of concern that affect the functioning of cultural institutions, professionalization pushes a greater capability to implement innovative interventions which boost the eco-museums' capability to meet the evolving expectations of relevant stakeholders.

From a practical perspective, the research findings suggest that both managerialization and professionalization are needed in the recipe for the eco-museums' digital transformation. They enact parallel effects on the digital turn of cultural institutions, stimulating a larger presence of ecomuseums in the cyber-physical context. Since they nurture a strategic focus on the enhancement of the visitors' experience, managerialization and professionalization are able to disrupt the resistances to change that tie cultural institutions to conventional management models. From this standpoint, managerialization and professionalization are expected to perform as stimuli to institutional and organizational change, inspiring a digital reconfiguration of eco-museums' structures and activities.

\section{References}

Agostino, D. and Arnaboldi, M. (2021), "From preservation to entertainment: Accounting for the transformation of participation in Italian state museums", Accounting History, Vol. 26 No. 1, pp. 102-122.

Ahmed, Z. A., Qaed, F. and Almurbati, N. (2020), "Enhancing Museums' Sustainability Through Digitalization", in Second International Sustainability and Resilience Conference: Technology and Innovation in Building Designs, IEEE: Sakheer, Bahrain.

Aiba, Y. and Sasatani, Y. (2004), "The proposal of the Digital Ecomuseum supporting system using WebGIS", Environmental System Research, Vol. 32 No. 1, pp. 365-372.

Babić, D., Vatan Kaptan, M. and Masriera Esquerra, C. (2019), "Heritage literacy: A model to engage citizens in heritage management", In M. Obad Šćitaroci, B. Bojanić Obad Šćitaroci and A. Mrđa (Eds.), Cultural Urban Heritage. Urban Book Series (pp. 1-18). Cham: Springer. 
Bae, E. S. and Lee, S. Y. (2012), "The International Sculpture Symposium in Icheon as local cultural values and a possibility of ecomuseum", Communications in Computer and Information Science, Vol. 353 No. 1, pp. 217-223.

Barile, S., Ciasullo, M. V., Troisi, O. and Sarno, D. (2017), "The role of technology and institutions in tourism service ecosystems: Findings from a case study", The TQM Journal, Vol. 29 No. 6, pp. 811-833.

Björkdahl, A. and Kappler, S. (2019), "The Creation of Transnational Memory Spaces: Professionalization and Commercialization", International Journal of Politics, Culture, and Society, Vol. 32 No. 1, pp. 383-401.

Brenton, S. and Bouckaert, G. (2020), "Managing public museums appropriately and consequentially: The distinctiveness and diversity of leading organizations", Public Administration Review. Published online ahead of print. Doi: 10.1111/puar.13323

Brida, J. G., Meleddu, M. and Pulina, M. (2016), "Understanding museum visitors' experience: a comparative study", Journal of Cultural Heritage Management and Sustainable Development, Vol. 6 No. 1, pp. 47-71.

Cappa, F., Rosso, F. and Capaldo, A. (2020), "Visitor-Sensing: Involving the Crowd in Cultural Heritage Organizations", Sustainability, Vol. 12 No. 4, p. 1445.

Carnegie, E. and Mccabe, S. (2008), "Re-enactment Events and Tourism: Meaning, Authenticity and Identity", Current Issues in Tourism, Vol. 11 No. 4, pp. 349-368.

Ciasullo, M. V., Gaeta, G., Monetta, G. and Rarità, L. (2015), "E-Cultural Value Co-Creation. A Proposed Model for the Heritage Management", Proceedings of the 18th "Excellence in Services" Conference, pp. 139-158, University of Verona, Italy.

Ciasullo M. V., Gaeta A., Gaeta M. and Monetta G. (2016). "New modalities for enhancing cultural heritage experience. The enabling role of digital technologies", Sinergie Italian Management Journal, Vol. 34 No. 1, pp.119-139.

Ciasullo M. V., Troisi O. and Cosimato S. (2018), "How Digital Platforms Can Trigger Cultural Value Co-Creation? A Proposed Model", Journal of Service Science and Management, Vol. 11 No. 2, pp. 161-181.

Colbence, E. and Sabatier, V. (2014), "Articulating Growth and Cultural Innovation in Art Museums. The Louvre's Business Model Revision", International Studies of Management \& Organization, Vol. 44 No. 4, pp. 9-25.

Conti, E., Vesci, M., Castellani, P. and Rossato, C. (2020), "The role of the museumscape on positive word of mouth: examining Italian museums", The TQM Journal, Published on-line ahead of print. Doi: 10.1108/TQM-12-2019-0306

Corsane, G., Davis, P., Elliott, S., Maggi, M., Murtas, D. and Rogers, S. (2007), "Ecomuseum Evaluation: Experiences in Piemonte and Liguria, Italy", International Journal of Heritage Study, Vol. 13 No. 2, pp. 101-116.

De Bernardi, P., Bertello, A. and Shams, R. S. (2019), "Logics Hindering Digital Transformation in Cultural Heritage Strategic Management: An Exploratory Case Study", Tourism Analysis, Vol. 24 No. 3, pp. 315-327.

Devine, C. and Tarr, M. (2019), "The Digital Layer in the Museum Experience", In T. Giannini and P. J. Bowen (Eds.), Museums and Digital Culture (pp. 295-307). Cham: Springer.

Dibitonto, M., Leszczynska, K., Cruciani, E. and Medaglia, C. M. (2020), "Bringing Digital Transformation into Museums: The Mu.SA MOOC Case Study", International Conference on Human-Computer Interaction, pp. 231-242, Cham: Springer.

Di Pietro, L. Guglielmetti Mugion, R. and Renzi, M. F. (2014), "Cultural technology district: a model for local and regional development", Current Issues in Tourism, Vol. 17 No. 7, pp. 640-656. 
Doğan, M. and Timothy, D. J. (2020), "Beyond tourism and taxes: the ecomuseum and social development in the Ak-Chin tribal community", Journal of Tourism and Cultural Change, Vol. 18 No. 2, pp. 133-149.

Donghai, S. (2008), "The Concept of the Ecomuseum and its Practice in China", Museum International, Vol. 60 Nos. 1/2, pp. 29-39.

Doukianou, S., Daylamani-Zad, D. and Paraskevopoulos, I. (2020), "Beyond Virtual Museums: Adopting Serious Games and Extended Reality (XR) for User-Centred Cultural Experiences", In F. Liarokapis, A. Voulodimos, N. Doulamis and A. Doulamis (Eds.), Visual Computing for Cultural Heritage. Springer Series on Cultural Computing (pp. 283-299). Cham: Springer.

Elgammal, I., Ferretti, M., Risitano, M. and Sorrentino, A. (2020), "Does digital technology improve the visitor experience? A comparative study in the museum context", International Journal of Tourism Policy, Vol. 10 No. 1, 47-67.

Errichiello, L., Micera, R., Atzeni, M. and Del Chiappa, G. (2019), "Exploring the implications of wearable virtual reality technology for museum visitors' experience: A cluster analysis", International Journal of Tourism Research, Vol. 21 No. 5, pp. 590-605.

Falk, J. H. and Sheppard, B. K. (2006), Thriving in the Knowledge Age: New Business Models for Museums and Other Cultural Institutions. New York, NY: Altamira Press.

Fernández-Hernández, R., Vacas-Guerrero, T. and García-Muiña, F. E. (2020), "Online reputation and user engagement as strategic resources of museums", Museum Management and Curatorship. Published on-line ahead of print. Doi: 10.1080/09647775.2020.1803114

Giannini, T. and Bowen, J. P. (2019), "Museums and Digitalism", In T. Giannini and J. P. Bowen (Eds.), Museums and Digital Culture (pp. 27-46). Cham: Springer.

Given, L. M. and McTavish, L. (2010), "What's Old Is New Again: The Reconvergence of Libraries, Archives, and Museums in the Digital Age", The Library Quarterly, Vol. 80 No. 1, pp. 7-32.

González, P. A., Vázquez, A. M. and Fernández, J. F. (2017), "Governance Structures for the Heritage Commons: La Ponte-Ecomuséu-Ecomuseum of Santo Adriano, Spain", In P. Gould and K. Pyburn (Eds.), Collision or Collaboration. One World Archaeology (pp. 153-170). Cham: Springer.

Grey, C. (1997), "Management as a technical practice: Professionalization or responsibilization?", Systems Practice, Vol. 10 No. 6, pp. 703-725.

Griffin-Kremer, C. (2020), "Back to the future. Squaring folk life and cultural diversity at the Alsace Ecomuseum", Folk Life, Vol. 58 No. 1, pp. 57-66.

Guarino, M., Di Palma, M. A., Mennini, T. and Gallo, M. (2020), "Digital transformation of cultural institutions: a statistical analysis of Italian and Campania GLAMs", Quality \& Quantity, Vol. 54, pp. 1445-1464.

Harrison, J. D. (1994), "Ideas of museums in the 1990s", Museum Management and Curatorship, Vol. 13 No. 2, pp. 160-176.

Hayes, A. F. (2018), Introduction to mediation, moderation, and conditional process analysis. A Regression-based approach. London: Guilford Press.

Hayes, A. F., Montoya, A. K. and Rockwood, N. J. (2017), "The analysis of mechanisms and their contingencies: PROCESS versus structural equation modeling", Australasian Marketing Journal, Vol. 25 No. 1, pp. 76-81.

Howard, P. (2002), "The eco-museum: Innovation that risks the future", International Journal of Heritage Studies, Vol. 8 No. 1, pp. 63-72.

Hwang, H. and Powell, W. W. (2009), "The Rationalization of Charity: The Influences of Professionalism in the Nonprofit Sector", Administrative Science Quarterly, Vol. 54 No. 2, pp. 268-298.

ISTAT (2018), Indagine sui musei e le istituzioni similari. Roma: ISTAT. 
Jelincic, D. A. and Senkic, M. (2017), "Creating a heritage tourism experience. The power of the senses", Etnoloska Tribina, Vol. 47 No. 40, pp. 109-126.

Kaur, N. S. (2019), "Empowering people through eco-museum: A case for the métis of Western Canada and meenas of Rajasthan", In K. Gayithri, B. Hariharan and S. Chattopadhyay (Eds.), Nation-Building, Education and Culture in India and Canada: Advances in Indo-Canadian Humanities and Social Sciences Research (pp. 92-110). Singapore: Springer.

Kim, J. Y. and Lee, J. Y. (2013), "Development of local cultural resources based on the concept of ecomuseum-focusing on Cheorwon, Gangwon Province", International Journal of Multimedia and Ubiquitous Engineering, Vol. 8 No. 5, pp. 297-302.

Lin, Y. C., Kao, J. Y. and Tsai, W. C. (2019), "From "Cane" to "Sugar": Empowering Tai Sugar History of Digital Design with "Interactive Visual Storytelling"", Lecture Notes in Computer Science, Vol. 11592, pp. 431-440.

Lindeqvist, C. and Oscarsson, P. (2004), "Eco Museum Bergslagen and the phenomenon of eco museums", Nordic Steel and Mining Review, Vol. 3 No. 1, p. 112.

Lindqvist, K. (2012), "Effects of Public Sector Reforms on the Management of Cultural Organizations in Europe", International Studies of Management \& Organization, Vol. 42 No. 2, pp. 9-28.

Liu, J. Y. (2014), "The living protection of original ecological environment-display of intangible cultural landscape based on the concept of eco-museum", Advanced Materials Research, Vol. 1030/1032, pp. 2420-2425.

Liu, J. and Tan, R. (2019), "The Display of Intangible Cultural Landscape Based on the Concept of Eco-Museum", Lecture Notes in Computer Science, Vol. 11577, pp. 71-79.

Llanos, J. (2015), "Is it possible a virtual-eco-museum? A Colombian Experience of Heritage's Communication through ICTs", in 2nd Digital Heritage International Congress: Analysis and Interpretation (pp. 679-682), Granada: IEEE.

Manna, R. and Palumbo, R. (2018), "What makes a museum attractive to young people? Evidence from Italy", International Journal of Tourism Research, Vol. 20 No. 8, pp. 508-517.

Mannoni, B. (1996), "Bringing museums online", Communications of the ACM, Vol. 29 No. 6, pp. 100-105.

Mason, M. (2020), "The elements of visitor experience in post-digital museum design", Design Principles and Practices, Vol. 14 No. 1, pp. 1-14.

Massing, K. (2019), "Learning to Let Go: The Process of Establishing an Ecomuseum in Southwell", Museum International, Vol. 71 Nos. 3/4, pp. 144-155.

Maye, L. A., Bouchard, D., Avram, G. and Ciolfi, L. (2017), "Supporting Cultural Heritage Professionals Adopting and Shaping Interactive Technologies in Museums", in Conference on Designing Interactive Systems (pp. 221-232). Edinburgh: Association for Computing Machinery.

McCall, V. and Gray, C. (2014), "Museums and the 'new museology': theory, practice and organisational change", Museum Management and Curatorship, Vol. 29 No. 1, pp. 19-35.

Milton-Smith, J. (1995), "Ethics as excellence: A strategic management perspective", Journal of Business Ethics, Vol. 14 No. 1, pp. 683-693.

Mingsiritham, K. and Chanyawudhiwan, G. (2019), "Development of the Virtual Museum of Nonthaburi", in 2nd International Conference on Image and Graphics Processing (pp. 121-124). Singapore: Association for Computing Machinery.

Minoska-Pavlovska, M. (2019), "Digital Strategies for Museums", Journal of Sustainable Development, Vol. 9 No. 22, pp. 145-161.

Müller, K. (2002), "Museums and Virtuality", Curator: The Museum Journal, Vol. 45 No. 1, pp. 2133. 
Myrczik, E. P. (2020), "Cultivating digital mediation: The implementation of publicly funded digital museum initiatives in Denmark", International Journal of Cultural Policy, Vol. 26 No. 2, pp. 239254.

Nofal, E., Panagiotidou, G., Reffat, R. M., Hameeuw, H., Boschloos, V. and Vande Moere, A. (2020), "Situated tangible gamification of heritage for supporting collaborative learning of young museum visitors", Journal on Computing and Cultural Heritage, Vol. 13 No. 1, p. 3.

Palumbo, R., Manna, R. and Cavallone, M. (2021), "The managerialization of museums and art institutions: perspectives from an empirical analysis", International Journal of Organizational Analysis, Published on-line ahead of print. Doi: 10.1108/IJOA-10-2020-2438

Pan, Y., He, L. and Shi, Y. (2012), "Practice of 'living museum' in the traditional architecture culture protection and renewal in south Fujian", Applied Mechanics and Materials, Vol. 209/211, pp. 98102.

Parry, R. (2019), "How Museums Made (and Re-made) Their Digital User", In T. Giannini and J. Bowen (Eds.), Museums and Digital Culture. Springer Series on Cultural Computing (pp. 275293). Cham: Springer.

Pesce, D., Neirotti, P. and Paolucci, E. (2019), "When culture meets digital platforms: value creation and stakeholders' alignment in big data use", Current Issues in Tourism, Vol. 22 No. 5, pp. 18831903.

Petrelli, D., Dulake, N., Marshall, M. T., Roberts, A., McIntosh, F. and Savage, J. (2018), "Exploring the Potential of the Internet of Things at a Heritage Site through Co-Design Practice", in 3rd Digital Heritage International Congress (pp. 151277). San Francisco, CA: IEEE.

Piancatelli, C., Massi, M. and Vocino, A. (2020), "The role of atmosphere in Italian museums: effects on brand perceptions and visitor behavioral intentions", Journal of Strategic Marketing, Published on-line ahead of print. Doi: 10.1080/0965254X.2020.1786846

Rivière, G. H. (2009), "The ecomuseum-an evolutive definition", Museum International, Vol. 37 No. 4, pp. 182-183.

Romanelli, M. (2020), "Museums and Technology for Value Creation", In J. Strandgaard Pedersen, B. Slavich and M. Khaire (Eds.), Technology and Creativity (pp. 181-210). Cham: Palgrave MacMillan.

Rossato, C. and Castellani, P. (2020), "The contribution of digitalisation to business longevity from a competitiveness perspective", The TQM Journal, Vol. 32 No. 4, pp. 617-645.

Sánchez, A.N. (2020), "From the Public Museum to the Virtual Museum. Communication in the Museum in Digital Environments. The Spanish Situation", in: Tak, A.A. and Pazos-López, Á. (Eds.), Socializing Art Museums Rethinking the Publics' Experience (pp. 65-81), Berlin: De Gruyter.

Sandifer, C. (2003), "Technological novelty and open-endedness: Two characteristics of interactive exhibits that contribute to the holding of visitor attention in a science museum", Journal of Research in Science Teaching, Vol. 40 No. 2, pp. 121-137.

Scrofani, L. and Ruggiero, L. (2013), "Museum networks in the Mediterranean area: Real and virtual opportunities", Journal of Cultural Heritage, Vol. 14 No. 3, pp. 75-79.

Striebing, C. (2017), "Professionalization and Voluntary Transparency Practices in Nonprofit Organizations", Nonprofit Management and Leadership, Vol. 28 No. 1, pp. 65-83.

Tesoriero, R., Gallud, J. A., Lozano, M. and Penichet, V. M. (2014), "Enhancing visitors' experience in art museums using mobile technologies", Information Systems Frontiers, Vol. 16, pp. 303-327.

Traboulsi, C., Frau, M. and Cabiddu, F. (2018), "Active seniors perceived value within digital museum transformation", The TQM Journal, Vol. 30 No. 5, pp. 530-553. 
Trunfio, M., Campana, S. and Magnelli, A. (2020), "Measuring the impact of functional and experiential mixed reality elements on a museum visit", Current Issues in Tourism, Vol. 23 No. 16, pp. 1990-2008.

Vermeeren, A. P., Shih, H. C., van der Laan, R., Calvi, L., Yoon, J. K. and Keller, I. (2018), "Designing Trajectories of Experiences: In Museums, Around Museums, or Including Museums", in A. Vermeeren, L. Calvi and A. Sabiescua (Eds.), Museum Experience Design (pp. 301-323). Cham: Springer.

Virto, N.R. and López, M.F.B. (2019), "Robots, Artificial Intelligence, and Service Automation to the Core: Remastering Experiences at Museums", in: Ivanov, S. and Webster, C. (Ed.), Robots, Artificial Intelligence, and Service Automation in Travel, Tourism and Hospitality (pp. 239-253), Bingley: Emerald Publishing Limited.

Wenchang, L. (2008), "Developments in China’s Digitalized Museums", Museum International, Vol. 60 Nos. 1/2, pp. 59-67.

Wiastuti, R. D., Lestari, N. S., Triana, I., Masatip, A., Ngatemin, N. and Mulyadi, B. (2020), "Enhancing visitor experiences at digital museum concept in Jakarta", Journal of Environmental Management and Tourism, Vol. 11 No. 6, pp. 1435-1444.

Williams, C. (1998), "The state of quality management in six leisure related research sites", The TQM Journal, Vol. 10 No. 2, pp. 95-103.

$\mathrm{Yu}$, J. and Wang, Y. (2020), "User interaction and scenario-based experience design for new media technology in museum spatial experience", Advances in Intelligent Systems and Computing, Vol. 954, pp. 263-270.

Zan, L. (2006), "Managerialization of Cultural Organizations and Institutional Settings: The Transformation into Foundations and Managerial Rhetoric", In L. Zan (Ed.), Managerial Rhetoric and Arts Organizations (pp. 94-114). London: Palgrave Macmillan.

Zutshi, A., Creed, A., Panwar, R. and Willis, L. (2021), "Corporate social responsibility (CSR): Curators' specific responses from Australian museums and art galleries", Current Issues in Tourism, Vol. 24 No. 5, pp. 651-667. 
Table 1 . The study sample $(n=126)$

Variable

Total

No. $\quad \%$

Geographical location

North-western Italy

$47 \quad 37.3$

North-eastern Italy

$27 \quad 21.4$

Central Italy

30

23.8

Southern Italy

7

5.6

Main Italian Islands

15

11.9

Subject area

Ethnography and anthropology

40

31.7

Local historical heritage

21

16.7

History

19

15

Archaeology

12

9.5

Modern and contemporary arts

11

8.7

Other

23

18.4

Year of foundation

1949 or earlier

Between 1950 and 1969

5

Between 1970 and 1989

4

3.2

Between 1990 and 1999

19

15.1

2000 or later

36

28.6

62

49.1

Ownership

Publicly owned

81

64.4

Privately owned

45

35.6

Number of employees

1 employee
Between 2 and 5 employees
Between 6 and 10 employees
Between 11 and 25 employees
26 employees and above
Do not know/Do not answer

17

15

xposition area (square meters)

50 and less

Between 51 and 500

Between 500 and 1,000

Between 1,001 and 2,500

2,501 and more

Do not know/Do not answer
17

13.5
$\%$ 
Table 2. The outcome of serial mediation models

\begin{tabular}{|c|c|c|c|c|}
\hline \multirow{3}{*}{$\begin{array}{l}\text { Model 1: } \\
\text { Model summary }\end{array}$} & \multicolumn{4}{|c|}{ Direct and indirect effects of Man on DP } \\
\hline & \multirow[t]{2}{*}{$\mathrm{R} 2=0.3271$} & \multirow{2}{*}{$\mathrm{DFs}=102$} & \multicolumn{2}{|c|}{$p=0.0000$} \\
\hline & & & \\
\hline Explanatory variables & Coeff. & $\mathrm{SE}$ & Prob. & \\
\hline Const. & 0.1047 & 0.3218 & 0.7457 & \\
\hline Man* $^{*}$ & 0.1511 & 0.0756 & 0.0482 & \\
\hline PC & 0.1361 & 0.0836 & 0.1067 & \\
\hline$V E^{* * *}$ & 0.2429 & 0.0886 & 0.0072 & \\
\hline Dimension (1 = large $)$ & 0.2632 & 0.1696 & 0.1238 & \\
\hline Ownership ( 1 = public) & 0.1031 & 0.1661 & 0.5632 & \\
\hline Geographical location (1 = Northern Italy) & 0.3227 & 0.1580 & 0.0436 & \\
\hline \multicolumn{5}{|l|}{ Indirect effects } \\
\hline Path & Effect & Boot SE & $\begin{array}{l}\text { Boot } \\
\text { LLCl }\end{array}$ & Boot ULCI \\
\hline Man $->P C->D P$ & 0.0569 & 0.0370 & -0.0292 & 0.1699 \\
\hline Man $>$ VE $>D P^{* *}$ & 0.0710 & 0.0336 & 0.0015 & 0.1703 \\
\hline Man $>$ PC $>$ VE $>$ DP & 0.0167 & 0.0137 & -0.0081 & 0.0702 \\
\hline Total indirect effect of Man on DP** & 0.1447 & 0.0526 & 0.0174 & 0.2997 \\
\hline Model 3: & \multicolumn{4}{|c|}{ Direct and indirect effects of Prof on DP } \\
\hline Model summary & $R 2=0.3482$ & $\mathrm{DF}=102$ & $p=0.000$ & \\
\hline \multicolumn{5}{|l|}{ Direct effect } \\
\hline Explanatory variables & Coeff. & $\mathrm{SE}$ & Prob. & \\
\hline Const. & 0.1906 & 0.3191 & 0.5515 & \\
\hline Prof** & 0.1870 & 0.0686 & 0.0076 & \\
\hline PC & 0.1480 & 0.0783 & 0.0616 & \\
\hline $\mathrm{VE}^{*}$ & 0.2167 & 0.0879 & 0.0154 & \\
\hline Dimension (1 = large $)$ & 0.1923 & 0.1710 & 0,2635 & \\
\hline Ownership ( 1 = public) & -0.0054 & 0.1701 & 0.9747 & \\
\hline Geographical location (1 = Northern Italy) & $0.3683^{*}$ & 0.1560 & 0.0202 & \\
\hline \multicolumn{5}{|l|}{ Indirect effects } \\
\hline Path & Effect & Boot SE & $\begin{array}{l}\text { Boot } \\
\text { LLCl }\end{array}$ & Boot ULCl \\
\hline Prof $->$ PC $>$ DP & 0.0456 & 0.0247 & -0.0209 & 0.1180 \\
\hline Prof $->V E->D P^{* *}$ & 0.0614 & 0.0275 & 0.0037 & 0.1506 \\
\hline Prof $>$ PC $>$ VE $>$ DP & 0.0137 & 0.0092 & -0.0014 & 0.0480 \\
\hline Total indirect effect of Prof on DP** & 0.1206 & 0.0362 & 0.0337 & 0.2256 \\
\hline
\end{tabular}

Model 2:

\begin{tabular}{llll}
\hline Model summary & R2 $=0.3406$ & DF2 $=102$ & $p=0.0000$
\end{tabular}

Direct effect

Const.

Man

$P C$

Dimension $(1=$ large)

Ownership (1 = public)

Ownership ( $1=$ public Geographical locat

(1 = Northern Italy)$$
\text { Path }
$$

Man $\rightarrow$ PC $>$ DS

Man $\rightarrow>$ VE $>>D^{* *}$

Man $\rightarrow$ PC $\rightarrow$ VE $\rightarrow$ DS

Coeff. $\quad$ SE $\quad$ Prob.

$\begin{array}{lll}-0.3897 & 0.3561 & 0.2764 \\ 0.1199 & 0.0836 & 0.1547\end{array}$

$\begin{array}{lll}0.1199 & 0.0836 & 0.1547 \\ 0.1807 & 0.0926 & 0.0537\end{array}$

$\begin{array}{lll}0.1807 & 0.0926 & 0.0537\end{array}$

$\begin{array}{lll}0.1807 & 0.0981 & 0.0001 \\ 0.0317 & 0.1877 & 0.8662\end{array}$

$\begin{array}{lll}0.4010 & 0.0981 & 0.0001 \\ 0.0317 & 0.1877 & 0.8662 \\ -0.1299 & 0.1838 & 0.4816\end{array}$

\begin{tabular}{lll}
0.2793 & 0.1748 & 0.1131 \\
\hline
\end{tabular}

$\begin{array}{ll}0.0276 \\ \text { Total indirect } \text { effect of Man on } \mathrm{DS}^{* *} & 0.2204\end{array}$

Model 4: $\quad$ Direct and indirect effects of Prof on DS

Model summary

Direct effect

Explanatory variables

Const.

Prof

$P C^{* * *}$

$\mathrm{VE}^{* * *}$

Dimension (1 = large)

Effect

Boot SE

Ownership (1 = public)

Geographical location

Indirect effects

(taly)

Path

Prof $\rightarrow$ PC $\rightarrow$ DS

Prof $\rightarrow$ VE $\rightarrow>D^{* *}$

Prof $->$ PC $->$ VE -> DS

Total indirect effect of Prof on DS*

R2 $=$

$\mathrm{R} 2=\quad \mathrm{DF}$
$\mathrm{DF}=$

$0.3279 \quad 102$

Coeff.

$-0.4240$

$-0.0238$

0.2390

0.4603

0.0833

$-0.0945$

SE

SE
0.3622
0.0779

0.0889
0.0998

0.1941

0.1931

0.0000
Prob.
0.2445
0.7602

0.7602

0.0084

0.0084
0.0000

Boot LLCl Boot ULCl

$\begin{array}{ll}-0.0326 & 0.2019\end{array}$

$0.0202 \quad 0.2515$

$\begin{array}{ll}-0.0130 & 0.0932 \\ 0.0647 & 0.3861\end{array}$

***: Significant at the 0.001 level

$*$ : Significant at the 0.01 level

*: Significant at the 0.05 level 
Table 3. The research hypotheses' testing

Hp \# Contents

Hp. 1 Managerialization triggers the eco-museums' digitization

Hp. 2 Professionalization positively affects the digital transformation of eco-museums

Hp. 3 People-centredness positively mediates the relationship between managerialization and the eco-museums' digital transformation

Hp. 4 People-centredness positively mediates the relationship between professionalization and the eco-museums' propensity to undertake a digital transformation

Hp. 5 The focus on visitors' experience positively mediates the relationship between managerialization and the digital transformation of eco-museums

Hp. 6 The focus on visitors' experience positively mediates the relationship between professionalization and the propensity of eco-museums to undertake a digital transformation

Hp. 7 People-centredness and the focus on visitors' experience serially mediate the relationship between

managerialization and the digital transformation of eco-

\section{museums}

Hp. 8 People-centredness and the focus on visitors' experience serially mediate the relationship between

professionalization and the propensity of eco-museums to undertake a digital transformation
Result

Partially supported

Partially supported

Not Supported

Not Supported

Supported

Supported

Not supported

Not supported

\section{Key findings}

Whilst managerialization was found to positively and significantly affect the digital presence of eco-museums, it did not influence their propensity to deliver digital cultural services to visitors

Professionalization triggered a greater digital presence of ecomuseums. However, it did not increase the predisposition of ecomuseums to exploit ICTs and digital tools to deliver cultural services People-centredness was not found to perform as a significant mediator in the relationship between managerialization and digitization

People-centredness was not found to perform as a significant mediator in the relationship between professionalization and digitization

A strategic focus on visitors' experience positively and significantly mediated the relationship between managerialization and digitization, boosting the digital presence of eco-museums and enhancing their web-based service delivery process

A strategic focus on visitors' experience positively and significantly mediated the relationship between professionalization and digitization, stimulating the recontextualization of eco-museums' presence in the digital domain and sustaining the delivery of digital cultural services

Even though the serial mediation effect was not statistically significant, the total indirect effect of mediators on the relationship between managerialization and digitization was positive and significant

Even though the serial mediation effect was not statistically significant, the total indirect effect of mediators on the relationship between professionalization and digitization was positive and significant 
Figure 1. Graphical representation of the statistical models
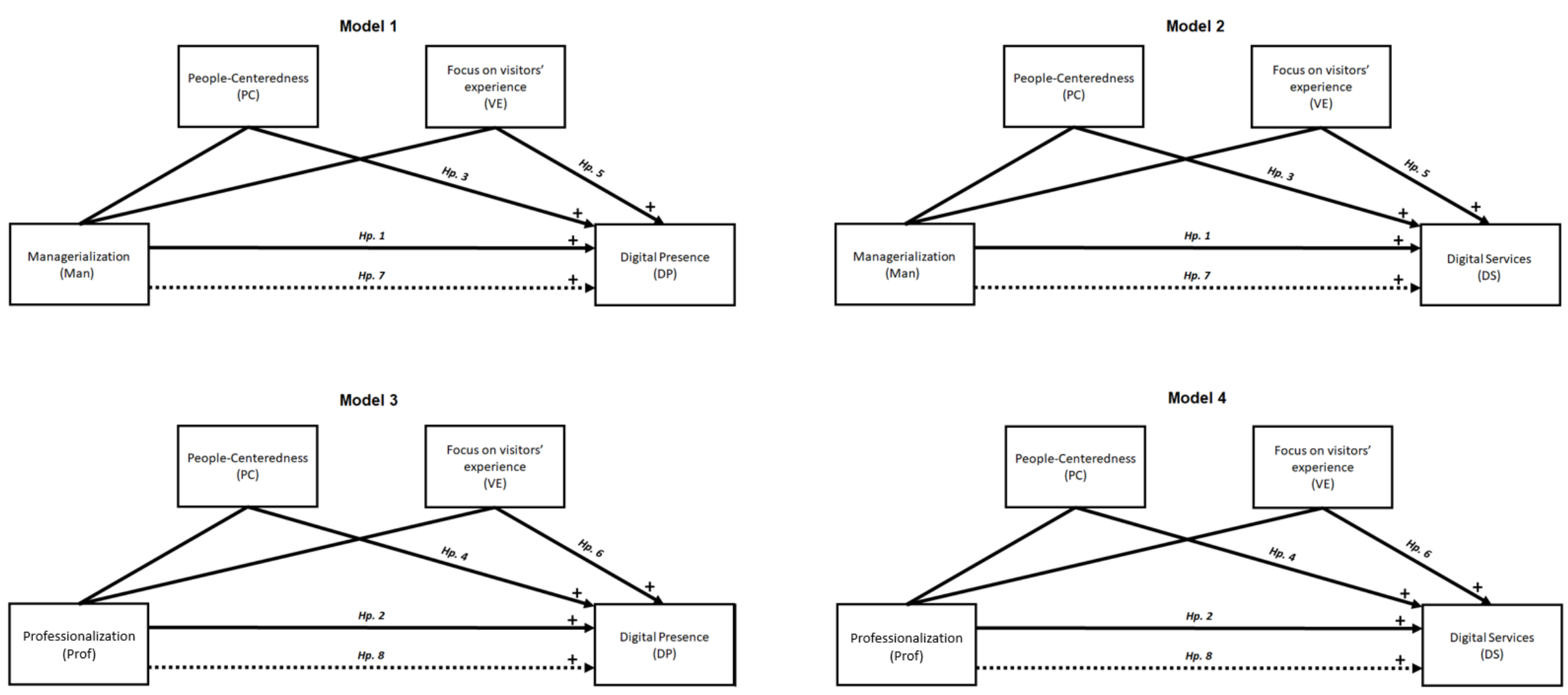

Legenda:

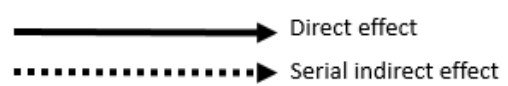

